\title{
Hubungan Faktor Predisposisi Dengan Perilaku Penggunaan Alat Pelindung Diri Di PT. PJB UBJ O\&M PLTU Indramayu
}

\author{
The Relationship between Predisposing Factors and the Behavior of Using Personal Protective \\ Equipment at PT. PJB UBJ $O$ \& M PLTU Indramayu
}

\section{${ }^{1}$ Rahmat Hadi Iskandar, ${ }^{2}$ H. Sutangi, ${ }^{3}$ Sri Handayani}

${ }^{1,2,3}$ Program Studi Kesehatan Masyarakat Universitas Wiralodra

\begin{abstract}
Abstrak
APD bagi pekerja merupakan kelengkapan yang harus dipakai pada saat melakukan pekerjaan yang disesuaikan dengan bahaya, resiko dan untuk menjaga keselamatan pekerja itu sendiri dan orang-orang disekitarnya. Tujuan dari penelitian ini untuk mengetahui hubungan faktor predisposisi dengan perilaku penggunaan Alat Pelindung Diri (APD) pada pekerja di PT. PJB UBJ O\&M PLTU Indramayu. Metode penelitian ini menggunakan pendekatan Cross Sectional. Dengan jumlah sampel peneliti sebanyak 35 orang. Analisis data uji statistik menggunakan Uji Chi Square. Variabel yang diteliti adalah faktor pengetahuan, sikap, pendidikan, masa kerja dan perilaku penggunaan (APD). Dalam pengumpulan data menggunakan observasi langsung dan kuesioner. Hasil penelitian adalah faktor pengetahuan ( $p$-value 0,000$)$, sikap ( $p$-value 0,003 ), pendidikan ( $p$-value 0,639$)$, masa kerja ( $p$-value 0,033$)$. Kesimpulan ada hubungan antara faktor pengetahuan, masa kerja dan sikap dengan perilaku penggunaan APD pada pekerja di PT. PJB UBJ O\&M PLTU Indramayu Tahun 2016. Pekerja diharapkan dapat saling menginggatkan rekan kerjanya apabila tidak menggunakan APD pada saat bekerja. Hal ini baik dilakukan untuk menghindari hal-hal yang tidak diinginkan terjadi pada saat bekerja.
\end{abstract}

Kata kunci : Pengetahuan, Sikap, Pendidikan, Masa kerja dan Perilaku Penggunaan Alat Pelindung Diri (APD).

\section{Abstrack}

Personal protective equipment (PPE) for workers is a completeness that should be worn when doing work that is tailored to the hazard, risk and to maintain the safety and the workers themselves and the people around him. The purpose of this study to predisposing factors to determine the relatiolship with the behavior of the use of personal protective equipment (PPE) for work at PT.
PJB UBJ O\&M Power plant Indramayu. Research methods this research using cross sectional approach. Woth samples researcher as many as 35 people. Data analysis statistical test using Chi-Square test.Variabel studied are the factors of knowledge, attitudes, education, length of service and the behaviorof the use of PPE. In the colletion of data using direct observation and questionnaires. Research result is factor of knowledge ( $p$-value 0,000 ), Attitudes ( $p$-value 0,003 ), Education ( $p$-value 0,639), Tenure ( $p$-value 0,033 ). Conclusion no correlation between knowledge, years of service and attitude with the behavior of the use of PPE for workers at PT. PJB UBJ O\&M Power Plant Indramayu year 2015. Workers are expected to remind each coworker when not using PPE at work. This is done to avoid the underasible things happen at work

Keywords : Knowledge, Attitudes, Education, Length of service and The behavior of the use Personal Provective Equipment (PPE)

\section{Pendahuluan}

Keselamatan dan Kesehatan Kerja merupakan salah satu aspek perlindungan tenaga kerja yang diatur dalam UndangUndang Nomor 13 Tahun 2003. Penerapan teknologi pengendalian keselamatan dan kesehatan kerja, diharapkan tenaga kerja dapat mencapai ketahan fisik, daya kerja dan tingkat kesehatan yang tinggi. Keselamatan dan kesehatan kerja adalah suatu usaha dan upaya untuk menciptakan perlidungan dan keamanan dari resiko perusahaan, masyarakat dan lingkungan. ${ }^{1}$

Semenjak terjadinya revolusi industri di Inggris pada akhir abad ke -18 dan awal abad ke-19, industri mulai berkembang ke seluruh 
Eropa Barat dan Amerika Utara kemudian keseluruh dunia. Dampak dari revolusi industri adalah meningkatnya jumlah tenaga kerja di kawasan industri yang sebelumnya para pekerja lebih banyak bekerja di sektor non industri. ${ }^{2}$

Peningkatan jumlah tenaga kerja dalam sektor industri tentu saja membawa dampak terhadap keadaan sosial masyarakat. Dampak yang ditimbulkan dari adanya perkembangan industri berupa dampak positif dan dampak negatif. Salah satu contoh dampak negatif yang ditimbulkan adalah penurunan kondisi kesehatan dan keselamatan para pekerja dikarenakan keadaan pekerja dilapangan atau di dunia industri belum dilindungi sistem pencegahan dan penanggulangan bahaya dunia industri terhadap keselamatan jiwa baik secara langsung maupun dalam jangka waktu yang lama. Untuk itu diperlukan suatu sistem penanggulangan bahaya yang disebut dengan kesehatan dan keselamatan kerja, dan salah satu indikator penting pelaksanaannya adalah penerapan Alat Pelindung Diri (APD). ${ }^{2}$

APD bagi pekerja merupakan kelengkapan yang harus dipakai pada saat melakukan pekerjaan yang disesuaikan dengan bahaya, resiko dan untuk menjaga keselamatan pekerja itu sendiri dan orang-orang disekitarnya. Kewajiban untuk menggunakan alat pelindung diri ini, telah menjadi kesepakatan bersama dengan pemerintah melalui departemen tenaga kerja dan transmigrasi. ${ }^{2}$

Data International Labor Organization (ILO), di Indonesia rata-rata pertahun terdapat 99.000 kasus kecelakaan kerja. Dari total tersebut, sekitar $70 \%$ berakibat fatal yaitu kematian dan cacat seumur hidup. Sementara menurut data Kementerian Tenaga Kerja dan Transmigrasi menyebutkan sampai tahun 2013 tidak kurang dari enam pekerja meninggal dunia setiap hari akibat kecelakaan kerja di Indonesia. Angka tersebut tergolongtinggi dibandingkan dengan Negara Eropa yang hanya sebanyak dua orang meninggal dunia setiap harinya karena kecelakaan kerja. ${ }^{3}$

Berdasarkan laporan dari PT Jamsostek mengenai jumlah kecelakaan kerja yang terjadi di Indonesia pada tahun 2006 di dapatkan bahwa total kasus yang terjadi sebanyak 95.624 kasus kecelakaan kerja yang terdiri dari cacat fungsi sebanyak 4.973 kasus, cacat sebagian sebanyak 2.918 kasus, cacat total sebanyak 122 kasus, jumlah kematian sebanyak 1.784 kasus dan yang mengalami sembuh sebanyak 85.827 kasus. ${ }^{4}$

Berdasarkan data 5 tahun terakhir pada Kantor Wilayah (Kanwil) IV PT Jamsostek Jawa Barat-Banten diketahui bahwa pada tahun 2008 jumlah kasus kecelakaan kerja 21.966 atau 60 kasus tiap hari. Tahun 2009 jumlah kasus kecelakaan kerja menurun menjadi 19.086 atau 55 kasus tiap hari. Tetapi pada tahun 2010 terjadi peningkatan kembali menjadi 27.865 kasus atau 77 kasus kecekalaan kerjasetiap harinya. Tahun 2011 mengalami penurunan jumlah angka kecelakaan kerja mennjadi 25.648 kasus atau 71 kasus kecelakaan kerja setiap harinya. Tahun 2012 jumlah angka kecelakaan kerja semakin menurun menjadi 22.172 kasus atau 61 kasus kecelakaan kerja setiap harinya. Dapat disimpulkan bahwa angka kecelakaan kerja tetap tinggi setiap tahunnyameski angka kecelakaan kerja cenderung turun. ${ }^{5}$

Jumlah kecelakaan kerja di Kabupaten Indramayu pada tahun (2012) terdapat 85 kasus, dibandingkan dengan tahun sebelumnya jumlah angka kecelakaan kerja mengalami penurunan yaitu angka kecelakaan kerja sebesar 111 kasus, sedangkan pada tahun 2013 kasus kecelakaan kerja mencapai 67 kasus, dimana kasus tersebut mencakup seluruh kecelakaan kerja baik sektor industry maupun non industri. ${ }^{6}$

APD bertujuan untuk melindungi para pekerja dari kemungkinan resiko bahaya yang dapat mengancam keselamatan jiwa. Tentu saja alat pelindung kerja harus mempunyai standarisasi dan spesifikasi sesuai dengan 
fungsinya untuk menanggulangi jenis bahaya tertentu. Untuk itu dalam hal ini akan dibahas macam-macam alat pelindung diri, perancangan, pembuatan, sertifikasi dan penerapannya dalam industri atau dunia kerja. ${ }^{2}$

Di dalam kegiatan sehari-hari dalam melakukan aktivitas, kita sering tidak menduga akan mendapatkan resiko kecelakaan pada diri kita sendiri. Banyak sekali masyarakat yang belum menyadari akan hal ini, termasuk di Indonesia. Baik di lingkungan kerja (perusahaan, pabrik, atau kantor), di jalan raya, tempat umum maupun di lingkungan rumah.

Masyarakat sering menyepelekan faktorfaktor tertentu karena mereka belum mendapat kecelakaan itu sendiri. Sehingga di perlukan cara untuk mencegah agar tidak terjadi kecelakaan yang tidak diinginkan. Selain pemberian peringatan diri dan pengertian kepada masyarakat, tentu dibutuhkan alat penunjang untuk mengurangi resiko terjadi kecelakaan. Disinilah alat pelindung diri (APD) dibutuhkan. Secara umum APD adalah salah satu usaha yang dapat mencegah kecelakaan guna memberikan perlindungan kepada pekerja. $^{7}$

Setiap aktivitas yang melibabkan manusia, mesin dan material yang melalui tahap proses produksi memiliki resiko bahaya dengan tingkatan resiko berbeda-beda yang memungkinkan terjadinya kecelakaan kerja dan penyakit akibat kerja. Resiko dan penyakit akibat kerja tersebut disebabkan karena adanya sumber-sumber bahaya akibat dari aktivitas kerja di temapat kerja.Umumnya di semua tempat kerja selalu terdapat sumber-sumber bahaya. Hampir tidak ada tempat kerja yang sama sekali bebas dari sumber bahaya. ${ }^{8}$

PT. Pembangkit Jawa Bali Unit Bisnis Jasa Operasi dan Maintenance PLTU Indramayu adalah pembangkit yang mengandalkan energi kinetik dari uap untuk menghasilkan energi listrik. Bentuk utama dari pembangkit listrik jenis ini adalah Generator yang dihubungkan ke turbin yang di gerakkan oleh tenaga kinetic dari uap panas/kering. Pembangkit listrik tenaga uap menggunakan berbagai macam bahan bakar terutama batu bara dan minyak bakar serta MFO untuk start up awal. Dari observasi yang dilakukan peneliti, ditemukan pekerja yang tidak menggunakan APD secara lengkap saat melakukan pekerjaan di unit boiler. Sedangkan proses produksi tersebut menggunakan peralatan yang mempunyai resiko terjadinya kecelakaan kerja dan penyakit akibat kerja sehingga perlu adanya penggunaan Alat Pelindung Diri (APD) sebagai salah satu upaya pencegahan terjadinya kecelakaan kerja.

\section{Metode}

Dalam melakukan penelitian ini, jenis penelitian yang digunakan jenis Observasi Analitik dengan menggunakan metode penelitian Croos Sectional, Croos Sectional adalah suatu penelitian yang mempelajari dinamikan korelasi antara faktor-faktor resiko dan efek, dengan cara pendekatan, observasi atau pengumpulan data sekaligus pada suatu saat (point time approach). ${ }^{9}$

Penelitian ini dilaksanakan di PT. PJB UBJ O\&M PLTU Indramayu 2016. Mulai dilaksanakan pada bulan Juni-Juli tahun 2016. Populasi dalam penelitian ini adalah pekerja PT. PJB UBJ O\&M PLTU Indramayu Tahun 2016 yaitu 35 pekerja. Teknik pengambilan sampel dalam penelitian ini menggunakan teknik total sampling yaitu pekerja PT. PJB UBJ O\&M PLTU Indramayu yang berjumlah 35 responden.

Analisis data menggunakan analisis univariat dan analisis bivariate. Uji statistik Chi-square dengan menggunakan program computer SPSS (Statistical Program For Social Science) versi 16.0. Uji statistik yang digunakan adalah Chi-Square $\left(X^{2}\right)$ dengan menggunakan $\alpha=0,05$ dan $95 \%$ Confiden Interval (CI) dan besar risk dihitung dengan menggunakan Odds Ratio (OR). untuk mengetahui kekuatan hubungan dua variabel antara variabel independent dan dependent, 
maka gunakan nilai koefisiensi kolerasi atua Sperman Correlation (SC). ${ }^{10}$

\section{Hasil}

Hasil univariat dalam penelitian ini meliputi karakteristik Pengetahuan, Sikap, Pendidikan, Masa kerja dan Perilaku Penggunaan Alat Pelindung Diri (APD). Hasil penelitian univariat disajikan dalam tabel 1-5.

\section{Analisis Univariat}

Tabel 1. Distribusi Frekuensi Responden Berdasarkan Pengetahuan Pada Pekerja

\begin{tabular}{cccc}
\hline No & Pengetahuan & Jumlah & $(\boldsymbol{\%})$ \\
1. & Kurang Baik & 7 & $20 \%$ \\
2. & Baik & 28 & $80 \%$ \\
& Total & 35 & $100 \%$ \\
\hline
\end{tabular}

Berdasarkan tabel 1 diatas dapat diketahui bahwa dari 35 pekerja sebanyak 7 orang $(20 \%)$ termasuk dalam kategori tingkat pengetahuan kurang baik, dan sebanyak 28 orang ( $80 \%$ ) termasuk dalam kategori tingkat pengetahuan baik, sebagian besar pekerja dalam kategori tingkat pengetahuan baik.

Tabel 2. Distribusi Frekuensi Responden Berdasarkan Sikap Pada Pekerja

\begin{tabular}{lccc}
\hline No & Sikap & Jumlah & $(\%)$ \\
1. & Negatif & 5 & 14,3 \\
2. & Positif & 30 & 85,7 \\
& Total & 35 & 100 \\
\hline
\end{tabular}

Berdasarkan tabel 2 diatas dapat diketahui bahwa dari 35 pekerja sebanyak 5 orang $(14,3 \%)$ mempunyai sikap negatif, dan sebanyak 30 orang $(85,7 \%)$ mempunyai sikap positif, sebagai besar pengetahuan pekerja dalam kategori sikap positif.
Tabel 3. Distribusi Frekuensi Responden Berdasarkan Pendidikan Pada Pekerja

\begin{tabular}{cccc}
\hline No & Pendidikan & Jumlah & $\mathbf{( \% )}$ \\
& & & \\
1 & Rendah & 29 & 82,9 \\
2 & Tinggi & 6 & 17,1 \\
& Total & 35 & 100 \\
\hline
\end{tabular}

Berdasarkan tabel 3 diatas dapat diketahui bahwa dari 35 pekerja sebanyak 29 orang $(82,9 \%)$ termasuk dalam kategori pendidikan rendah, dan sebanyak 6 orang $(17,1 \%)$ termasuk dalam kategori pendidikan tinggi, sebagai besar masa kerja pekerja dalam kategori pendidikan rendah.

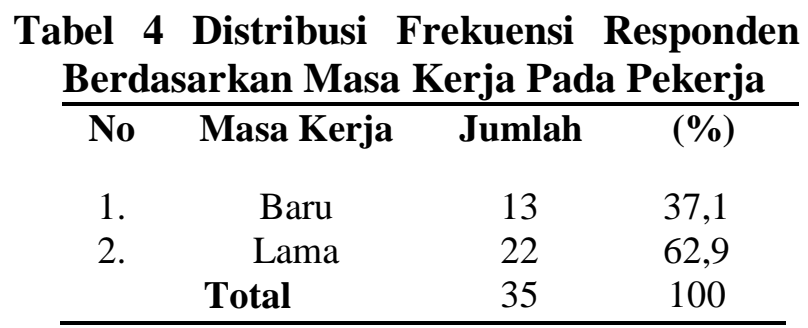

Berdasarkan tabel 4 diatas dapat diketahui bahwa dari 35 pekerja sebanyak 13 orang $(37,1 \%)$ termasuk dalam kategori baru, dan sebanyak $22(62,9 \%)$ pekerja termasuk dalam kategori lama, sebagian besar masa kerja pekerja dalam kategori lama.

\section{Tabel 5. Distribusi Frekuensi Responden Berdasarkan Perilaku Pada Pekerja

\begin{tabular}{lccc}
\hline No & Perilaku & Jumlah & $\mathbf{( \% )}$ \\
1. & Kurang Baik & 9 & 25,7 \\
2. & Baik & 26 & 74,3 \\
& Total & 35 & 100 \\
\hline
\end{tabular}

Berdasarkan tabel 5 diatas dapat diketahui bahwa dari 35 pekerja sebanyak 9 orang $(25,7 \%)$ termasuk dalam kategori kurang, dan sebanyak 26 ( 74,3\%) pekerja termasuk dalam kategori baik, sebagian besar perilaku penggunaan APD masuk dalam kategori baik. 


\section{Analisis Bivariat}

Tabel 6. Hubungan Pengetahuan Dengan Perilaku Penggunaan APD Pada Pekerja

\begin{tabular}{|c|c|c|c|c|c|c|c|c|c|}
\hline \multirow{3}{*}{ No } & \multirow{3}{*}{ Pengetahuan } & \multirow{2}{*}{\multicolumn{2}{|c|}{$\begin{array}{c}\text { Perilaku } \\
\text { Penggunaan } \\
\text { APD }\end{array}$}} & \multirow{3}{*}{$\begin{array}{c}\text { Jumla } \\
\mathbf{h}\end{array}$} & \multirow{3}{*}{$\begin{array}{c}\text { P- } \\
\text { Value }\end{array}$} & \multirow{3}{*}{ SC } & \multirow{3}{*}{$\mathbf{R R}$} & \multicolumn{2}{|c|}{$95 \% \mathrm{CI}$} \\
\hline & & & & & & & & \multirow[t]{2}{*}{ Lower } & \multirow[t]{2}{*}{ Upper } \\
\hline & & $\begin{array}{c}\text { Kurang } \\
\text { baik }\end{array}$ & Baik & & & & & & \\
\hline \multirow[t]{2}{*}{1.} & Kurang & 6 & 1 & 7 & & & & & \\
\hline & & $17,1 \%$ & $2,9 \%$ & $20,0 \%$ & & & & & \\
\hline \multirow[t]{4}{*}{2.} & Baik & 3 & 25 & 28 & 0,000 & 0,686 & 8,000 & 2,633 & 24,304 \\
\hline & & $8,6 \%$ & $71,4 \%$ & $80,0 \%$ & & & & & \\
\hline & Total & 9 & 26 & 35 & & & & & \\
\hline & & $25,7 \%$ & $74,2 \%$ & $100 \%$ & & & & & \\
\hline
\end{tabular}

Berdasarkan tabel 6 diketahui bahwa dari 7 pekerja yang pengetahuan kurang pekerja yang kurang baik menggunakan APD adalah 6 orang dan pekerja yang baik menggunakan APD adalah 1 orang, sedangkan dari pekerja yang mempunyai pengetahuan baik pekerja yang kurang baik menggunakan APD terdapat 3 orang dan yang baik menggunakan APD adalah 25 orang. Hasil uji statistik menggunakan uji Chi Square didapatkan nilai $P$-value 0,000 , karena nilai $P$-value $<0,05$ sehingga Ho ditolak, artinya ada hubungan antara pengetahuan dengan perilaku penggunaan APD. Untuk mengetahui tingkat kekuatan hubungan dapat dilihat dari Spearman Correlation (SC), dari dua variable yaitu pengetahuan dengan perilaku penggunaan APD, berdasarkan hasil perhitungan dengan uji statistik Spearman Correlation dengan menggunakan SPSS versi 16.0 menunjukan hubungan kuat antara pengetahuan pekerja dengan perilaku penggunaan APD yaitu dengan nilai $\mathrm{SC}=$ 0,686 atau 6,86 \% dengan demikian dapat disimpulkan bahwa terdapat hubungan kuat antara pengetahuan dengan perilaku penggunaan APD pada pekerja di area boiler PT. PJB UBJ O\&M PLTU Indramayu Tahun 2016. Nilai Relatif Risk (RR) 8,000 dan nilai CI $95 \% \quad(2,633-24,304)$ sehingga RR bermakna. Ini berarti bahwa pekerja mempunyai pengetahuan kurang baik lebih beresiko 8,000 kali tidak menggunakan APD, dibandingkan dengan pekerja yang mempunyai pengetahuan baik.

Tabel 7 Hubungan Sikap dengan Perilaku Penggunaan APD Pada Pekerja

\begin{tabular}{|c|c|c|c|c|c|c|c|c|c|}
\hline \multirow{3}{*}{ No } & \multirow{3}{*}{ Sikap } & \multirow{2}{*}{\multicolumn{2}{|c|}{$\begin{array}{c}\text { Perilaku } \\
\text { penggunaan APD }\end{array}$}} & \multirow{3}{*}{ Jumlah } & \multirow{3}{*}{$\begin{array}{c}\text { P- } \\
\text { Value }\end{array}$} & \multirow{3}{*}{ SC } & \multirow{3}{*}{$\mathbf{R R}$} & \multicolumn{2}{|c|}{$95 \%$ CI } \\
\hline & & & & & & & & Lower & Upper \\
\hline & & $\begin{array}{c}\text { Kurang } \\
\text { baik }\end{array}$ & Baik & & & & & & \\
\hline \multirow[t]{2}{*}{1.} & Negatif & 4 & 1 & 5 & & & & & \\
\hline & & $11,4 \%$ & $2,9 \%$ & $14,3 \%$ & & & & & \\
\hline \multirow[t]{4}{*}{2.} & Positif & 5 & 25 & $30 \%$ & 0,003 & 0,507 & 4,800 & 1,928 & 11,952 \\
\hline & & $14,3 \%$ & $71,4 \%$ & $85,7 \%$ & & & & & \\
\hline & Total & 9 & 26 & 35 & & & & & \\
\hline & & $25,7 \%$ & $74,3 \%$ & $100 \%$ & & & & & \\
\hline
\end{tabular}

Berdasarkan tabel 7 diketahui bahwa dari 5 pekerja yang sikap negatif pekerja yang kurang baik menggunakan APD adalah 4 orang dan pekerja yang baik menggunakan APD adalah 1 orang, sedangkan dari pekerja yang mempunyai sikap positif pekerja yang 
kurang baik menggunakan APD terdapat 5 orang dan yang baik menggunakan APD adalah 25 orang. Hasil uji statistik menggunakan uji Chi Square didapatkan nilai $P$-value 0,003 , karena nilai $P$-value $<0,05$ sehingga Ho ditolak, artinya ada hubungan antara sikap dengan perilaku penggunaan APD. Untuk mengetahui tingkat kekuatan hubungan dapat dilihat dari Spearman Correlation (SC), dari dua variable yaitu sikap dengan perilaku penggunaan APD, berdasarkan hasil perhitungan dengan uji statistik Spearman Correlation dengan menggunakan SPSS versi 16.0 menunjukan hubungan kuat antara sikap pekerja dengan perilaku penggunaan APD yaitu dengan nilai $\mathrm{SC}=0,507$ atau $0,57 \%$ dengan demikian dapat disimpulkan bahwa terdapat hubungan kuat antara sikap dengan perilaku penggunaan APD pada pekerja di area boiler PT. PJB UBJ O\&M PLTU Indramayu Tahun 2016.

Berdasarkan table 7 diketahui bahwa nilai Relatif Risk (RR) 4,800 dan nilai CI 95\% (1,928-11,952) sehingga RR bermakna. Ini berarti bahwa pekerja mempunyai sikap negatif lebih beresiko 4,800 kali tidak menggunakan APD, dibandingkan dengan pekerja yang mempunyai sikap positif.

Tabel 8. Hubungan Pendidikan Dengan Perilaku Penggunaan APD Pada Pekerja

\begin{tabular}{|c|c|c|c|c|c|c|c|c|c|}
\hline \multirow{3}{*}{ No } & \multirow{3}{*}{$\begin{array}{c}\text { Tingkat } \\
\text { Pendidikan }\end{array}$} & \multirow{2}{*}{\multicolumn{2}{|c|}{$\begin{array}{c}\text { Perilaku } \\
\text { Penggunaan APD }\end{array}$}} & \multirow{3}{*}{ Jumlah } & \multirow{3}{*}{$\begin{array}{c}\text { P- } \\
\text { Value }\end{array}$} & \multirow{3}{*}{ SC } & \multirow{3}{*}{$\mathbf{R R}$} & \multicolumn{2}{|c|}{$95 \% \mathrm{CI}$} \\
\hline & & & & & & & & Lower & Upper \\
\hline & & $\begin{array}{c}\text { Kurang } \\
\text { Baik }\end{array}$ & Baik & & & & & & \\
\hline \multirow[t]{2}{*}{1.} & Rendah & 7 & 22 & 29 & & & & & \\
\hline & & $20,0 \%$ & $62,9 \%$ & $82,9 \%$ & & & & & \\
\hline \multirow[t]{4}{*}{2.} & Tinggi & 2 & 4 & 6 & 0,639 & 0,079 & 724 & 197 & 2,664 \\
\hline & & $5,7 \%$ & $11,4 \%$ & $17,1 \%$ & & & & & \\
\hline & Total & 9 & 26 & 35 & & & & & \\
\hline & & $25,7 \%$ & $74,3 \%$ & $100 \%$ & & & & & \\
\hline
\end{tabular}

Berdasarkan tabel 8 diketahui bahwa dari 29 pekerja yang pendidikan rendah pekerja yang kurang baik menggunakan APD adalah 7 orang dan pekerja yang baik menggunakan APD adalah 22 orang, sedangkan dari pekerja yang mempunyai pendidikan tinggi pekerja yang kurang baik menggunakan APD terdapat 2 orang dan yang baik menggunakan APD adalah 4 orang. Hasil uji statistik menggunakan uji Chi Square didapatkan nilai $P$-value 0,639 , karena nilai $P$-value $<0,05$ sehingga Ho tidak ditolak, artinya tidak ada hubungan antara pendidikan dengan perilaku penggunaan APD. Untuk mengetahui tingkat kekuatan hubungan dapat dilihat dari Spearman Correlation (SC), dari dua variable yaitu pendidikan dengan perilaku penggunaan APD, berdasarkan hasil perhitungan dengan uji statistik Spearman Correlation dengan menggunakan SPSS versi 16.0 menunjukan hubungan lemah antara pendidikan pekerja dengan perilaku penggunaan APD yaitu dengan nilai $\mathrm{SC}=0,079$ atau $0,79 \%$ dengan demikian dapat disimpulkan bahwa terdapat hubungan lemah antara pendidikan dengan perilaku penggunaan APD pada pekerja di area boiler PT. PJB UBJ O\&M PLTU Indramayu Tahun 2016. Tabel 8 diketahui bahwa nilai Relatif Risk (RR) 724 dan nilai CI 95\% (197-2,664) sehingga RR tidak bermakna. Ini berarti bahwa pekerja mempunyai pendidikan rendah beresiko 724 kali tidak menggunakan APD, dibandingkan dengan pekerja yang mempunyai pendidikan tinggi. 
Tabel 9. Hubungan Masa Kerja Dengan Perilaku Penggunaan APD Pada Pekerja

\begin{tabular}{|c|c|c|c|c|c|c|c|c|c|}
\hline \multirow{3}{*}{ No } & \multirow{3}{*}{$\begin{array}{l}\text { Masa } \\
\text { Kerja }\end{array}$} & & & \multirow{3}{*}{ Jumlah } & \multirow{3}{*}{$\begin{array}{c}\text { P- } \\
\text { Value }\end{array}$} & \multirow{3}{*}{ SC } & \multirow{3}{*}{$\mathbf{R R}$} & \multicolumn{2}{|c|}{$95 \% \mathrm{CI}$} \\
\hline & & \multicolumn{2}{|c|}{ Penggunaan APD } & & & & & Lower & Upper \\
\hline & & $\begin{array}{c}\text { Kurang } \\
\text { baik }\end{array}$ & Baik & & & & & & \\
\hline \multirow[t]{2}{*}{1.} & Baru & 6 & 7 & 13 & & & & & \\
\hline & & $17,1 \%$ & $20,0 \%$ & $37,1 \%$ & & & & & \\
\hline \multirow[t]{4}{*}{2.} & Lama & 3 & 19 & 22 & 0,033 & 0,359 & 3,385 & 1,015 & 11,287 \\
\hline & & $8,6 \%$ & $54,3 \%$ & $62,9 \%$ & & & & & \\
\hline & Total & 9 & 25 & 35 & & & & & \\
\hline & & $25,7 \%$ & $74,3 \%$ & $100 \%$ & & & & & \\
\hline
\end{tabular}

Berdasarkan tabel 9 diketahui bahwa dari 13 pekerja yang masa kerja baru pekerja yang kurang baik menggunakan APD adalah 6 orang dan pekerja yang baik menggunakan APD adalah 7 orang, sedangkan dari pekerja yang mempunyai masa kerja lama pekerja yang kurang baik menggunakan APD terdapat 3 orang dan yang baik menggunakan APD adalah 19 orang. Hasil uji statistik menggunakan uji Chi Square didapatkan nilai $P$-value 0,033 , karena nilai $P$-value $<0,05$ sehingga Ho ditolak, artinya ada hubungan antara masa kerja dengan perilaku penggunaan APD. Untuk mengetahui tingkat kekuatan hubungan dapat dilihat dari Spearman Correlation (SC), dari dua variable yaitu masa kerja dengan perilaku penggunaan APD, berdasarkan hasil perhitungan dengan uji statistik Spearman Correlation dengan menggunakan SPSS versi 16.0 menunjukan hubungan kuat antara masa kerja pekerja dengan perilaku penggunaan APD yaitu dengan nilai $\mathrm{SC}=0,359$ atau $3,59 \%$ dengan demikian dapat disimpulkan bahwa terdapat hubungan sedang antara masa kerja dengan perilaku penggunaan APD pada pekerja di area boiler PT. PJB UBJ O\&M PLTU Indramayu Tahun 2016. Tabel 9 diketahui bahwa nilai Relatif Risk (RR) 3,386 dan nilai CI $95 \% \quad(1,015-11,287)$ sehingga RR bermakna. Ini berarti bahwa pekerja mempunyai masa kerja baru lebih beresiko 3,386 kali tidak menggunakan APD, dibandingkan dengan pekerja yang mempunyai masa kerja lama.

\section{Pembahasan}

\section{Analisis Univariat}

\section{Tingkat Pengetahuan Pekerja Tentang Penggunaan APD}

Dari penelitian yang dilakukan kepada 35 responden didapatkan hasil bahwa responden yang memiliki pengetahuan kurang baik yaitu sebanyak 7 pekerja (20\%) dan pengetahuan kurang baik sebanyak 28 pekerja $(80 \%)$. Pengetahuan merupakan domain yang paling penting untuk terbentuknya tindakan seseorang, maka dari itu perilaku yang didasari dengan pengetahuan dan kesadaran akan bertambah lama dibandingkan perilaku yang tidak didasari ilmu pengetahuan dan kseadaran. ${ }^{11}$

Dalam penelitian ini sebagian besar pengetahuan pekerja di area boiler PT. PJB UBJ O\&M PLTU Indramayu terhadap penggunaan APD termasuk kategori pengetahuan baik.

\section{Tingkat Sikap Pekerja Tentang Penggunaan APD Pada Pekerja}

Dari penelitian yang dilakukan kepada 35 responden didapatkan hasil bahwa responden yang memiliki sikap negatif yaitu sebanyak 5 pekerja $(14,3 \%)$ dan sikap baik sebanyak 30 pekerja $(85,7 \%)$. Dalam kata lain, fungsi sikap 
belum merupakan tindakan (reaksi terbuka) atau aktifitas, akan teatapi merupakan predisposisi perilaku (tindakan) atau reaksi tertentu. $^{12}$

Dalam penelitian ini sebagian besar sikap pekerja di area boiler PT. PJB UBJ O\&M PLTU Indramayu terhadap penggunaan APD termasuk kategori sikap positif.

\section{Tingkat Pendidikan Pekerja Tentang Penggunaan APD Pada Pekerja}

Dari penelitian yang dilakukan kepada 35 responden didapatkan hasil bahwa responden yang memiliki pendidikan rendah yaitu sebanyak 29 pekerja $(82,9 \%)$ dan pendidikan tinggi sebanyak 6 pekerja $(17,1 \%)$. tingkat pendidikan seseorang akan berpengaruh dalam memberikan respon terhadap sesuatu yang datang dari luar, mereka yang mempunyai pendidikan lebih tinggi akan member respon yang rasional dari pada merika yang berpendidikan rendah. Orang yang mempunyai pendidikan tinggi diharapkan lebih peka terhadap kondisi keselamatanya, sehingga lebih baik dalam memanfaatkan fasilitas kesehatan. $^{13}$

Dalam penelitian ini sebagian besar pendidikan pekerja di area boiler PT. PJB UBJ O\&M PLTU Indramayu terhadap penggunaan APD termasuk kategori pendidikan rendah.

\section{Tingkat Masa Kerja Pekerja Tentang Penggunaan APD Pada Pekerja}

Dari penelitian yang dilakukan kepada 35 responden didapatkan hasil bahwa responden yang memiliki masa kerja baru yaitu sebanyak 13 pekerja $(37,1 \%)$ dan masa kerja lama sebanyak 22 pekerja $(62,9 \%)$. Tenaga kerja yang mempunyai tenaga kerja lama akan lebih terampil danberpengalaman di dalam mengerjakan pekerjaannya sehingga hasilnya akan lebih baik dan aman. ${ }^{14}$

Dalam penelitian ini sebagian besar masa kerja pekerja di area boiler PT. PJB UBJ O\&M PLTU Indramayu terhadap penggunaan APD termasuk kategori masa kerja lama.

\section{Tingkat Perilaku Pekerja Tentang Penggunaan APD Pada Pekerja}

Dari penelitian yang dilakukan kepada 35 responden terdapat 35 pekerja sebanyak 26 pekerja $(74,3 \%)$ perilaku baik dan 9 pekerja $(25,7)$ termasuk perilaku kurang baik. Perilaku merupakan suatu fungsi dari interaksi antara seseorang individu dengan lingkungan, yang berarti bahwa keduanya secara langsung menentukan perilaku. ${ }^{15}$

\section{Analisis Bivariat}

\section{Hubungan Pengetahuan Dengan Perilaku Penggunaan APD Pada Pekerja}

Dari hasil uji Chi Square, diperoleh nilai probabilitas ( $P$-value) sebesar 0,000 ( $P$-value $<0,05)$ berarti Ho ditolak sehingga dapat disimpulkan artinya ada hubungan antara pengetahuan dengan perilaku penggunaan ADP pada pekerja di area boiler PT. PJB UBJ O\&M PLTU Indramayu.

Pengetahuan adalah hasil penginderaan manusia, atau hasil tahu seseorang terhadap obyek melalui indera yang dimilikinya Pengetahuan atau kognitif merupakan domain yang sangat penting untuk terbentuknya tindakan seseorang (open behavior). Pengetahuan yang didasari oleh pengalaman dan penelitian akan lebih mengarahkan seseorang unt uk berperilaku dengan baik. ${ }^{11}$

Hasil penelitian ini sesuai dengan penelitian Muharni Eka Putri (2004) bahwa terdapat hubungan pengetahuan dengan praktek dalam pemakaian APD pada pekerja unit spiring PT. ${ }_{13}$ Apac Corpora Bawen ( $p$-value) sebesar 0,005. 


\section{Hubungan Sikap Dengan Perilaku Penggunaan APD Pada Pekerja}

Sikap merupakan reaksi atau respon seseorang yang masih tertutup terhadap stimulasi atau objek. Sikap secara nyata menunjukan konotasi adanya kesesuaian reaksi terhadap stimulasi tertentu. Sikap belum merupakan suatu tindakan atau aktifitas, akan tetapi merupakan predisposisi tindakan atau perilaku. ${ }^{16}$

Dari hasil uji Chi Square, diperoleh nilai probabilitas ( $P$-value) sebesar 0,003 ( $P$-value $<0,05)$ berarti Ho ditolak sehingga dapat disimpulkan artinya ada hubungan antara sikap dengan perilaku penggunaan ADP pada pekerja di area boiler PT. PJB UBJ O\&M PLTU Indramayu.

Hasil penelitian ini juga sesuai dengan penelitian Dedek Mulyanti (2008) yaitu terdapat terhadap hubungan antara sikap dengan penggunaan APD dalam usaha persalinan normal di Rumah Sakit Meuraxa Banda Aceh (p-value sebesar 0,019).

\section{Hubungan Pendidikan Dengan Perilaku Penggunaan APD Pada Pekerja}

Pendidikan yaitu suatu proses penyampaian bahan atau materi yang dilakukan oleh pendidik kepada sasaran pendidikan guna mencapai perubahan tingkah laku. Seseorang dengan latar belakang pendidikan formal tinggi akan mempunyai tingkat pengetahuan dan penalaran yang tinggi serta persepi yang beragam terkait sesuatu hal dibandingkan dengan seseorang dengan latar belakang pendidikan formal rendah. ${ }^{17}$

Dari hasil uji Chi Square, diperoleh nilai probabilitas (P-value) sebesar 0,639 ( $P$-value $<0,05)$ sehingga dapat disimpulkan artinya tidak ada hubungan antara pendidikan dengan perilaku penggunaan ADP pada pekerja di area boiler PT. PJB UBJ O\&M PLTU Indramayu.

Hasil penelitian ini sesuai dengan penelitian yang dilakukan Wekoyla (2012) bahwa tidak terdapat hubungan antara pendidikan dengan penggunaan APD pada tindakan pertolongan persalinan di Rumah Sakit Umum Provinsi Sulawesi Tenggara dan Rumah Sakit Umum Kota Kendari denagn ( $p$-value sebesar $0,780){ }^{18}$

\section{Hubungan Masa Kerja dengan Perilaku Penggunaan APD Pada Pekerja}

Pengalaman kerja merupakan faktor penting yang dapat mempengaruhi terjadinya kecelakaan kerja. Dimana pengalaman kerja diperoleh dari masa kerja yang lama atau lebih dari satu tahun. Pekerja yang lebih banyak memiliki pengalaman akan lebih mengerti bahaya yang timbul dari pekerjaan yang mereka lakukan sehingga mereka lebih berhati-hati dansemakin sadar untuk melindungi tubuhnya dengan patuh menggunakan APD saat bekerja. ${ }^{19}$

Dari hasil uji Chi Square, diperoleh nilai probabilitas ( $P$-value) sebesar 0,033 ( $P$-value $<0,05)$ berarti Ho ditolak sehingga dapat disimpulkan artinya ada hubungan antara masa kerja dengan perilaku penggunaan ADP pada pekerja di area boiler PT. PJB UBJ O\&M PLTU Indramayu.

Hasil penelitian ini sesuai dengan penelitian yang dilakukan Denisa Listy Kiay Demak (2013) bahwa ada hubungan antara masa kerja dengan implementasi penggunaan APD pada perawat di Rumah Sakit Asshobirin Tangerang Selatan Tahun (2013) dengan $(p=$ sebesar $0,008) .^{20}$ 


\section{Kesimpulan}

Dari hasil penelitian yang dilakukan pada pekerja di area Boiler PT. PJB UBJ O\&M PLTU Indramayu Tahun 2016 Tentang Hubungan Faktor Predisposisi Dengan Perilaku Penggunaan Alat Pelindung Diri (APD), dapat ditarik beberapa kesimpulan sebagai berikut :

1. Berdasarkan menggunakan uji statistik univariat diketahui bahwa dari 35 pekerja yang diteliti :

a Pengetahuan pada pekerja di area boiler PT. PJB UBJ O\&M PLTU Indramayu yaitu 7 (20\%) pengetahuan kurang baik dan $28(80 \%)$ pengetahuan baik.

b Sikap pada pekerja di area boiler PT. PJB UBJ O\&M PLTU Indramayu yaitu $5(14,3 \%)$ negatif dan $30 \quad(85,7 \%)$ positif.

c Pendidikan pada pekerja di area boiler PT. PJB UBJ O\&M PLTU Indramayu yaitu $29(82,9 \%)$ pendidikan rendah dan $6(17,1 \%)$ pendidikan tinggi.

d Masa kerja pada pekerja di area boiler PT. PJB UBJ O\&M PLTU Indramayu yaitu $13(37,1 \%)$ baru dan $22(62,9 \%)$ lama.

e Gambaran perilaku penggunaan APD pada pekerja di area boiler PT. PJB UBJ O\&M PLTU Indramayu yaitu 9 $(25,7 \%)$ berperilaku kurang baik dan $26(74,3 \%)$ perilaku baik.

2. Berdasarkan analisis bivariat dapat diketahui bahwa :

a Adanya hubungan yang bermakna antara pengetahuan dengan perilaku penggunaan APD pada pekerja di area boiler PT. PJB UBJ O\&M PLTU Indramayu $(p$-value $=0,000)$

b Adanya hubungan yang bermakna antara sikap dengan perilaku penggunaan APD pada pekerja di area boiler PT. PJB UBJ O\&M PLTU Indramayu $(p$-value $=0,003)$ c Tidak adanya hubungan yang bermakna antara pendidikan dengan perilaku penggunaan APD pada pekerja di area boiler PT. PJB UBJ O\&M PLTU Indramayu $(p$-value $=0,639)$

d Adanya hubungan yang bermakna antara masa kerja dengan perilaku penggunaan APD pada pekerja di area boiler PT. PJB UBJ O\&M PLTU Indramayu $(p$-value $=0,033)$

\section{Saran}

Berdasarkan hasil dan kesimpulan penelitian diatas, maka penulis mencoba memberikan saran dan masukan sebagai pertimbangan perbaikan kedepannya, yaitu :

1. Bagi Perusahaan

a. Perusahaan diharapkan lebih memperketat pengawasan penggunaan APD dan mensosialisasikan peraturan penggunaan APD kepada para pekerja

b. PT. PJB UBJ O\&M PLTU Indramayu telah memiliki peraturan tersendiri menyangkut penggunaan ADP , tetapi belum diterapkan secara maksimal. Agar penggunaan APD lebih meningkat, sebaikannya peraturan yang ada dipertegas dengan diberlakukannya sansi dan penghargaan terhadap pekerja yang melanggar dan mematuhi peraturan tersebut.

2. Bagi Pekerja

a. Perlu adanya peningkatan kesadaran dan pemahaman terkait penggunaan APD untuk pentingnya menjaga keselamatan dan kesehatan pada saat bekerja.

b. Pekerja diharapkan dapat saling menginggatkan rekan kerjanya apabila tidak menggunakan APD pada saat bekerja. Hal ini baik dilakukan untuk menghindari hal-hal yang tidak diinginkan terjadi pada saat bekerja. 


\section{Daftar Pustaka}

1. Cecep, D.S. 2014. Keselamatan dan Kesehatan Kerja.Yogyakarta : Gosyen Publishing.

2. Adi, Putra. 2010. Dasar Hukum Alat Pelindung Diri. http://www.safetydo.com/2010/12/ dasar hokum alat pelindung diri.html. Diakses Tanggal 29 Januari 2016.

3. Andrian, 2013. Ancaman Kecelakaan kerja di Indonesia Masih Tinggi. http:/www.bpjs ketenaga kerjaan.go.id/content/news.php?id=315 1. Di Akses Tanggal 11 Mei 2016.

4. Depnakertrans RI.2007. Kecelakaan kerja dan faktor-faktor yang berhubungan di Indonesia (Berdasarkan data PT. Jamsostek Tbk), volume $\quad x x x x \quad$ No.3.Majalah keselamatan kerja dan hiperkes. JuliOktober. Jakarta

DepnakertransRIPress.

5. Jamsostek. 2012. Kasus Kecelakaan Kerja Tahun 2011. Disnakertrans Jawa Barat.

6. Disnakertrans. $2013 . \quad$ Kasus Kecelakaan Kerja Tahun 2012. Disnakertrans Indramaayu 2013.

7. Muthia, Friska. 2011. Tujuan, manfaat, jenis dan kegunaan APD. https://mysafety

shoes.wordpress.Com/2011/10/27/ tujuan, manfaat, jenis dan kegunaan APD. Diakses Tanggal 29 Januari 2016.

8. Sahab, Syukri. 1997. Tehnik Manajemen Keselamatan dan Kesehatan Kerja. Jakarta: PT. Bina Sumber Daya Manusia.

9. Notoatmodjo, Soekidjo, Prof. Dr. 2012. Metodologi Penelitian Kesehatan, Jakarta: Rineka Cipta.

10. Wijoyo, Sutarto. 2010. Psikologi Industri dan Organisasi, Jakarta: Kencana Prenada Media Group.
11. Notoatmodjo, S. 2003. Pendidikan dan Perilaku Kesehatan. Jakarta: Rineka Cipta.

12. Notoatmodjo, S. 2007. Promosi Kesehatan dan Ilmu Perilaku. Jakarta: Rineka Cipta.

13. Muharni, Eka Purti. 2004. FaktorFaktor Yang Berhubungan Dengan Praktek Dalam Pemakaian APD pada pekerja unit spiring PT. Apac Corpora Bawen 2004.

14. Anoraga, Pandji. 2001. Pengantar Pasar Modal Indonesia. MediasoftIndonesia. Jakarta.

15. Miftah Thoha, 2003. Kepemimpinan Dalam Menejemen. Jakarta: PT. Dara Grafindo.

16. Linggasari. 2008. Fakto-Faktor Yang Mempengaruhi Perilaku Penggunaan Alat Pelindung Diri di Departemen Engineering PT. Kiat Plup dan Paper Tbk. Tanggerang Tahun 2001. Skripsi Progaram Sarjana Kesehatan Masyarakat Universitas Indonesia.

17. Siagian, T. 2001. Teori Motivasi dan Aplikasi. Jakarta: PT. Prima Aksara.

18. Wekoyla. 2012. Faktor-Faktor Yang Berhubungan dengan penggunaan APD pada tindakan pertolongan persalinan di Rumah Sakit Umum Provinsi Sulawesi Tenggara dan Rumah Sakit Umum Kota Kendari. Tesis Program Studi Sarjana Kesehatan Masyarakat UI 2012.

19. Hapidin, Rahman. 2007. Gambaran factor-faktor yang mempengaruhi Kepatuahan Terhadap Penggunaan APD Pada Pekerja Bagian Operasi dan Pemeliharaan di PT. Indonesia Power unit bisnis Pembangkitan Komajang tahun 2007. Tesis Program Study Magister Kesehatan Masyarakat Universitas Jenderal Soedirman.

20. Denisa Listy Kiay Demak. 2013. Analisis Penyebab Perilaku Aman Bekerja Pada Perawat Di RS Islam 
Asshobirin Tangerang Selatan Tahun 2013. Tesis Program Studi Kesehatan Masyarakat Fakultas Kedokteran Dan Ilmu Kesehatan UniversitasIslam Negeri Syarif Hidayatullah Jakarta 2014. 